\title{
Ultrasound in the acute scrotum: the truth and the false
}

\author{
Ottavio Adorisio, ${ }^{1}$ Paola Marchetti, ${ }^{1}$ Francesco De Peppo, ${ }^{1}$ Massimiliano Silveri ${ }^{2}$
}

'Department of Pediatric Surgery, Bambino Gesù Children's Hospital, Palidoro, Italy

${ }^{2}$ Department of Pediatric Urology and Nephrology, Bambino Gesù Children's Hospital, Passoscuro, Rome, Italy

\section{Correspondence to} Dr Ottavio Adorisio, o.adorisio@yahoo.it
To cite: Adorisio 0 , Marchetti P, De Peppo F, et al. BMJ Case Rep Published online: [please include Day Month Year] doi:10.1136/bcr-2013009011

\section{DESCRIPTION}

A 16-year-old boy was admitted to our emergency department (ED) with a 6-day history of left scrotal swelling associated with pain progressively worsening. About 6 days previously he had a scrotal trauma that occurred during a football match (blow with a ball) leading to left scrotal swelling and local pain that spontaneously disappeared after half an hour but reappeared the day after. His physician suggested oral administration of antibiotic (amoxicillin), non-steroidal anti-inflammatory drugs and local ice application. Because of worsening of pain and swelling the patient was admitted to our ED. Upon physical examination he presented an enlarged and painful left scrotum. Ultrasound examination showed a parenchymal fracture of the testis without blood flow at colour Doppler evaluation (figure 1), but surgical exploration revealed spermatic cord torsion with no signs of parenchymal rupture (figure 2). Left orchiectomy was carried out. Six months after the procedure the patient underwent a placement of left testicular prosthesis. Torsion of the testis is the most common urological emergency and should be included in the differential diagnosis of scrotal trauma. ${ }^{1}$ Clinical suspicion of testicular torsion is a serious indication for prompt surgical exploration of post-traumatic acute scrotum. Scrotal trauma is commonly associated with severe injuries to the scrotal contents including haematoma, fracture or rupture of the testicle and peritesticular structures. ${ }^{2}$ Reliance on the history and physical examination alone is hazardous and the inaccuracy of those elements has been well documented now for decades. Sensitivity of ultrasound for diagnosing testicular

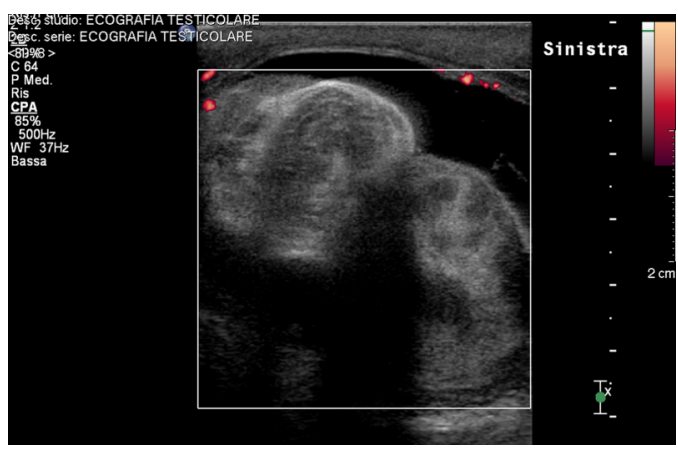

Figure 1 Testicular ultrasound showing a parenchymal fracture of the left testis.

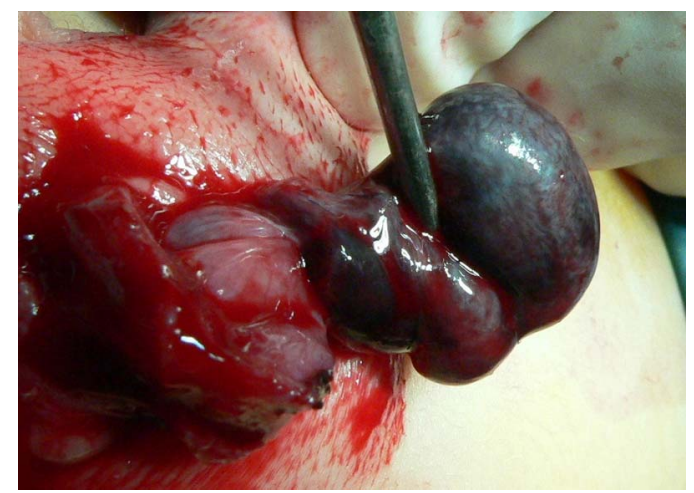

Figure 2 Intraoperative picture showing left testicular torsion without signs of fractures.

rupture reaches $100 \%$, discontinuity of tunica albuginea, contour abnormality and heterogeneous echotexture are the signs of testicular rupture.

Concurrently, although the accuracy of imaging is quite good, it is also well documented to have a degree of error and inaccuracy. ${ }^{3}$

\section{Learning points}

- Torsion of the testis is the most common urological emergency and should be included in the differential diagnosis of scrotal trauma.

- Ultrasound imaging in the case of acute scrotum have a degree of error and inaccuracy.

- Suspicion of testicular torsion would be considered in case of post-traumatic acute scrotum leading to prompt surgical exploration.

Competing interests None.

Patient consent Obtained.

Provenance and peer review Not commissioned; externally peer reviewed.

\section{REFERENCES}

1 Mellick LB. Torsion of the testicle: it is time to stop tossing the dice. Pediatr Emerg Care 2012;28:80-6.

2 Davis JE, Silverman M. Scrotal emergencies. Emerg Med Clin North Am 2011;29:469-84.

3 Sung EK, Setty BN, Castro-Aragon I. Sonography of the pediatric scrotum: emphasis on the Ts-torsion, trauma, and tumors. AJR Am J Roentgenol 2012;198:996-1003. 
Copyright 2013 BMJ Publishing Group. All rights reserved. For permission to reuse any of this content visit http://group.bmj.com/group/rights-licensing/permissions.

BMJ Case Report Fellows may re-use this article for personal use and teaching without any further permission.

Become a Fellow of BMJ Case Reports today and you can:

- Submit as many cases as you like

- Enjoy fast sympathetic peer review and rapid publication of accepted articles

- Access all the published articles

- Re-use any of the published material for personal use and teaching without further permission

For information on Institutional Fellowships contact consortiasales@bmjgroup.com

Visit casereports.bmj.com for more articles like this and to become a Fellow 